\title{
STUDY OF THE PREVALENCE, RISK FACTORS AND PUBLIC HEALTH IMPLICATION OF LISTERIA MONOCYTOGENES IN READY TO EAT CAMEL MEAT (CAMELUS DROMEDARIES) COLLECTED FROM TAMBOOL TOWN SLAUGHTER POINT AND ITS BUTCHER SHOPS, (ALJAZEERA STATE, CENTRAL SUDAN), 2018.
}

\author{
Mohammed Babiker.M.H*1'2; Mohamed abdelsalam Abdalla ${ }^{3}$; Elfadil, Abdelhamid.A.M ${ }^{213}$, Nagwa Abdalla \\ Mohamed Abdalla ${ }^{3}$.
}

1. Department of Preventive Medicine and Public Health, College of Veterinary Medicine, University of Al butana, Tamboul, P.O.Box 200 Rufaa, Sudan.

2. Animal Resources Services Directorate, Ministry of Environment, Water and Agriculture, 11195 P.O. Box 7878 Riyadh, Kingdom of Saudi Arabia.

3. Department of Veterinary Preventive Medicine and Public Health, College of Veterinary Medicine, Sudan University of Science and Technology, Hillat Kuku, Khartoum North, Sudan.

\begin{abstract}
Listeriosis is one of the important food-borne bacterial zoonotic diseases caused by Listeria monocytogenes. This disease is becoming an emerging bacterial disease, with low incidence but high case fatality rate. The present study was undertaken to determine the presence of Listeria monocytogenes in raw camel meat in Tambool town's abattoir and butcher shops. A cross-sectional study was conducted from May to September 2017 to isolate Listeria monocytogenes from swab samples taken from camel meat in abattoir, butcher shops and equipment's. A total of 865 swab samples comprising of 380 from the abattoir, 380 from butcher shops were collected using systematic random sampling technique and 105 swabs were collected from equipment's. A pretested questionnaire survey was conducted to assess the hygienic practices in the abattoir and butcher shops as well as possible risk factors associated with contamination of meat. Listeria monocytogenes was isolated and identified using standard bacteriological techniques. The overall prevalence of Listeria monocytogenes identified was $5.5 \%$ and $6.6 \%, 2.6 \%, 7.6 \%$ from abattoir, butcher shops and equipment's, respectively. In addition, the presence of Listeria monocytogenes was associated with unclean working environment and improper handling of meat before it reaches to the consumer. Preventive measures to avoid the presence of pathogenic Listeria monocytogenes in raw meat and meat products should be undertaken, emphasizing the need for improved hygienic practices during meat production and also during distribution of the final products.
\end{abstract}

Key words: Tambool Town, Listeria monocytogenes, Prevalence, Camel meat. 


\section{Introduction:}

Animal resources in the Sudan comprise of sheep, goat, cattle, camel, poultry and wildgame. Establishing a hygienic program for exported mutton is required in order to enable the Sudan facing the international trade parameters. This entails a vital need to improve the slaughter houses and to impose strict hygienic measures to provide healthy and wholesome meat to fulfill the international requirements (International Committee of Microbiological Standards of Foods (ICMSF), 1986; Gracey et al., 1999).

Meat is one of the highly perishable foods because of its high nutritional contents, enzymatic action and the presence of microorganisms (bacteria, yeasts and molds) which may result in oxidative rancidity, discolouration, mouldiness, off flavour, and sliminess. The major source of these deteriorative changes being microorganisms, this renders the meat unacceptable and unfit for human consumption (Ajiboye et al., 2011).

Bacteria which are responsible for the most food-borne disease contaminate meat directly and indirectly from animal excreta at slaughter process; also they may be transferred from the surfaces, utensils and other equipment (Arnold International Students, 1993; Yen, 2003). The external contamination of meat constitutes a constant problem in most developing countries abattoirs where they are potential sources of infection (Lawrie, 1979). The microbial surface contamination of carcasses has been repeatedly reported to have a significant effect on the meat shelf life. Moreover, Contaminants may also include pathogens which can penetrate into the meat (Elmossalami and Wassef, 1971).

Slaughtering is a suitable progress for the contamination of the carcass by partially pathogenic bacteria (Forsythe and Hayes, 1998) so that all surfaces in contact with meat should be taken under control or kept clean to minimize the risk of bacterial contamination (Butterorth-Heineinann, 2000). Poor sanitary methods spread such diseases as Salmonellosis, Cholera, E.coli food poisoning and Listeriosis that cause Contamination of the meat, a serious public health concern (Neil Trent et al., 2002).

The microbiological contamination of carcasses occurs mainly during processing and manipulation, such as skinning, evisceration, storage and distribution at slaughterhouses and retail establishments (Gill, 1998; Abdalla et al., 2009). Most microbial contaminants of carcasses represent commensal bacteria, some microorganisms such as Salmonella spp., Escherichia coliO157::H7, and Listeria monocytogenes pose a threat to-consumer health (Gustavsson and Borch, 1993; Samelis et al., 2001). There were significant increases in total bacterial counts-at skinning points than that at washing operations; also, dirty workers hands, clothes and equipments of the slaughterhouse acted as intermediate sources of contamination of meat (Gill, 1998; Gilmour et al., 2004; AbdelSadig, 2006; Abdalla et al., 2009). Ali (2007), recorded high contamination level on flanksite and lower contamination level on rump sites during skinning.

Listeria are Gram-positive, non-spore-forming, and non-acid-fast rods. Six species of Listeria are recognized L. murrayi, L. grayi, L. ivanovii, L. innocua, L. welshimeri and L. monocytogenes. The primary pathogenic species is L. monocytogenes (James et al., 2005). 
Listeria monocytogenes and other Listeria species are widely spread in the environment. Possible Listeria cross-contamination by employees, equipment, and environment surfaces, animal skin, food additives, packing material and many other sources has been reported (Marinšek \& Grebenc 2002; Griffiths 2003), thus effective sanitation programmes in the slaughtering and meat processing plants are strongly recommended (Frank et al., 2003; Doyle et al., 2004; Heir 2004). The carcasses and their products may be contaminated during slaughtering and meat processing, thus they can be recognized as feasible transmission routes of Listeria to humans (Nesbakken et al., 1996; EFSA 2006). Listeria can potentially become airborne owing to the sanitation maintenance and meat processing, especially within solid particles suspended into the air, as single organisms or in droplets in the form of aerosols created by the use of water sprayers (Spurlock \& Zottola 1991).

In Sudan, hygienic measures to control microbial contamination of meat are unsatisfactorily applied. Storage at refrigerator temperatures is still one of the most effective practices for improving the safety of fresh meat. However, some butcheries still use poor refrigeration, in addition, the retail raw meat in most of butcheries is presented exposed to environmental pollution which might lead to increased bacterial contamination.

The objectives of this study are: to know the prevalence and risk factors of $L$. monocytogenes in red camel meat in Tambool town Slaughterhouse and butcher shops, to investigate the microbial contamination of camel raw meat, and to identify the main points of contamination of camel carcasses during slaughtering operations.

\section{Materials and Methods: Study area:}

The study was carried out in Tamboul Town, Aljazeera state, Central Sudan. Tamboul Town is the largest city of Al butana Governorate. The area is characterized by moderate rainfall, the highest percentage of rain-falls occurs during the long rainy season from August to November.

East of the Aljazeera is a patch lining the eastern Blve Nile and it is bordered to the north by Khartoum state, on the south by the west-east area of the Nile and on the east, by the states of Kassala and Gedaref._It's a geographical zone which less approximately between Latitude 130,40' and 170, 50' North and Longitude 320, 40' and 360, 00' East. Tamboul city located near the city of Ruffaa located east Aljunied sugar factory and is famous for its camel population. Tamboul city famous for its trade, where is the Tamboul market of the largest markets in the Sudan as it is the biggest market for camel in Sudan.

\section{Study abattoir and origin of samples:}

Tamboul Town Abattoir Enterprise was established before 7 years ago, and is located at the heart of Tamboul Town. The abattoir is a high output abattoir in the Albutana area providing $80 \%$ of the daily meat requirements of the city's residents. Most of the camel slaughtered at the abattoir are adult males of local camel. Other Species of animals slaughtered include bovine, ovine, caprine. In the abattoir, regular meat inspection is being 2020 May Edition | www.jbino.com | Innovative Association 
conducted by meat inspectors as well as veterinarians from the Ministry of Agriculture. The abattoir is not divided into clean and dirty areas, so that after skinning and evisceration, carcasses do not follows the clean lines.

The swab sample was collected from camel meat from the Tamboul town Abattoir Enterprise and butcher shops located in the city. Furthermore, swab samples were collected from equipments like knives.

\section{Study population and sample size determination:}

The study samples represented camel meat and equipments like knives.

The approximate sample size required was determined, according to Thrusfield (2005), from expected prevalence of $50 \%$ with defined precision of $5 \%$ and level of confidence of $95 \%$.

$n=1.96^{2} P \exp (1-P \exp ) / d 2$

Where:

$\mathrm{n}=$ required sample size

$\mathrm{P} \exp =$ expected prevalence

d $=$ desired absolute precision

Therefore, by using estimated prevalence of $50 \%$ in raw meat of camel and taking a confidence interval of $95 \%$ and $5 \%$ absolute precision, the minimum sample size required for this study was 800 camel meat swab samples. A total of 865 samples will be taken randomly from selected carcasses (neck, shoulder, thigh, and liver) comprising of 380 camel meat swab samples from the Tamboul Abattoir, 380 camel meat swab samples from the butcher shops were used for the study. In addition, 105 swab samples from equipments like knives, cutting tables and hooks (Table 1).

The samples were transported to the Microbiological laboratory of the Faculty of Veterinary Medicine, Sudan University of Science and Technology. Upon arrival the ISO 11290-1 method was used.

\section{Study methodology:}

\section{Study design:}

The study was conducted to determine the prevalence of L. monocytogenes from September 2016 to March 2017 in red camel meat slaughtered at Tamboul Town Abattoir Enterprise at the Microbiological Laboratory of the Faculty of Veterinary Medicine, Sudan University of Science, Khartoum, Sudan. On each sampling day, all the required samples (camel meat swab samples, equipment swab samples) were taken.

\section{Sampling technique:}

2020 May Edition | www.jbino.com | Innovative Association 
In Tambool Town Municipal Abattoir, the maximum numbers of animals are slaughtered on Saturday and Tuesday and mainly during marketing days. Carcasses were examined just after evisceration before washing. The meat was swabbed without distinction of race, sex or age at Tamboul Town Abattoir Enterprise and different butcher shops during several visits. The carcasses were chosen in a random sampling method and examined just after the stage of evisceration.

All samples were collected aseptically using disposable gloves to avoid contamination, and the samples were labeled with necessary information including the date of sampling, sample code and sample type. The selected meat was swabbed aseptically using the method described in ISO11290-1 (1996) by placing sterile template $(10 \times 10 \mathrm{~cm})$ on specific sites of a carcass. A sterile cotton tipped swab $(2 \times 3 \mathrm{~cm})$ fitted with shaft, was first soaked in an approximately $10 \mathrm{ml}$ of buffered peptone water (Oxoid Ltd., Hampshire, England) rubbed first horizontally and then vertically several times on the carcasses. The neck, shoulder, thigh, liver and knife, which were sites exposed for contamination and were chosen for sampling. On completion of the rubbing process, the cotton swab was left in the test tube. Finally, the carcass swabs taken were kept in a transport medium (buffered peptone water) and transported to the Microbiology Laboratory of the College of Veterinary Medicine, Sudan University of Science (SUST), Khartoum, Sudan, for microbiological analysis. On arrival, the samples were stored in a refrigerator at $4^{\circ} \mathrm{C}$.

\section{Method of Sterilization:}

Dry heat:

\section{Hot air oven:}

For sterilization, clean glass containers were wrapped in foil or put in stainless steel cans at a temperature of $160^{\circ} \mathrm{C}$ for one hour (Stainer 1986).

\section{Flaming:}

Flaming was used to sterilize the mouth of bottles, cotton plugged tubes and glass slides. It was done by exposing the object to the direct flame for about half to one second.

\section{Moist Heat:}

\section{Autoclaving:}

Autoclaving was used for sterilization of media and materials that couldn't withstand the dry heat. The temperature was $115^{\circ} \mathrm{C}-121^{\circ} \mathrm{C}$ under 10-15 pounds pressure for 15-20 minutes (Barrow and Feltham, 1993).

\section{Culture Media:}

Culture media were prepared according to Bridson (2006), unless otherwise specified.

\section{Agar:}


Agar can be obtained as shreds, flakes, granules or powder and is made from certain types of seaweed. The usefulness of its unusual gelling properties for bacteriological work was recognized by Frau Hesse, (Bulloch, 1938; Hitchens \& Leikind, 1939).

\section{Isolation and identification of listeria monocytogenes:}

The techniques recommended by the International Standards Organization (ISO $11290-1$, 1996) and the French Association for Standardization (AFNOR, 1993) were employed for the isolation and identification of Listeria monocytogenes.

\section{Isolation of listeria monocytogenes:}

Primary selective enrichment:

Each sample unit which are kept in buffered peptone water was mixed thoroughly to ensure the homogeneity of its contents and about $0.1 \mathrm{ml}$ unit was obtained aseptically in to $10 \mathrm{ml}$ of prepared listeria enrichment broth (LEB) followed by mixing and the sample was kept inside incubator and incubated at $30^{\circ} \mathrm{C}$ for $48 \mathrm{hrs}$.

\section{Secondary selective enrichment:}

The secondary selective enrichment medium with full concentration of selective agents was employed. From the pre-enrichment culture (Listeria Enrichment Broth), after being well mixed $0.1 \mathrm{ml}$ was transferred into $10 \mathrm{ml}$ of Half Fraser broth and was incubated at $35^{\circ} \mathrm{C}$ for 24 hours.

\section{Questionnaire survey:}

Questionnaire survey was conducted to the meat value chains in the study sites and a detailed and organized questionnaire format was designed. A pre-structured questionnaire was prepared and pre-tested. 50 butchers and 50 abattoir workers were surveyed. The questions and answers were written in English and entered. Data management and analysis:

The data were analyzed using SPSS software (Statistical Package for the Social Sciences, version 20, SSPS Inc. Chicago, IL, USA). All bacterial counts were analyzed using ANOVA. Statistical significance was set at a P-value of $\leq 0.05$.

\section{Results:}

\section{Prevalence of $L$. monocytogenes in abattoir and butcher shops:}

From a total of 865 samples, the overall prevalence of L. monocytogenes was (5.5\%) (Table 2). The prevalence of $L$. monocytogenes varied between sources of samples. Out of each 380 samples collected from the abattoir and butcher shops, the prevalence of $L$. monocytogenes were $6.6 \%$ and $2.6 \%$, respectively. The result was higher in abattoir than butcher shops and there was significant difference in prevalence of $L$. monocytogenes from these sources of samples $(\mathrm{p}<0.05)$ Out of 105 equipment samples collected from both in abattoir and butcher shops, the prevalence of $L$. monocytogenes was $7.6 \%$. There was no 
significant difference in prevalence of $L$. monocytogenes between abattoir and butcher shops ( $p>0.05)$ (Table 4).

\section{Prevalence of Listeria monocytogenes in abattoir and butcher shops:}

Out of the total 760 (380 from abattoir and 380 from butcher shops) swab samples examined during the study period $25(6.6 \%)$ and $10(2.6 \%)$ were positive for $L$. monocytogenes.

The overall prevalence of $L$. monocytogenes from both abattoir and butcher shops $(N=760)$ was $4.6 \%$. The prevalence in abattoir was higher with statistically significant difference $(P=0.01)$. The prevalence of $L$. monocytogenes in abattoir was almost three times (OR=3.1, $\mathrm{Cl}=2.1-7.2$ ) higher than that in butchers shops (Figure 2 and Table (3)).

\section{Contamination rate of Listeria monocytogenes in equipments}

Table (4) indicated the contamination rate of $L$. monocytogenes in meat surface contact materials (hook, cutting table and knife). Knife was found to have the highest prevalence (10\%) followed by cutting table (7.5\%), whereas no positive samples were found in hooks (0.0\%).

Although there was no even one sample positive for hooks, there is no statistically significant difference among hook, knife and cutting table ( $P=0.1$ ) (figure 3 ).

\section{Findings of questionnaire survey:}

\section{Findings of questionnaire survey in abattoir:}

A total of 50 respondents from the abattoir were surveyed. About (20\%) of the abattoir workers have completed high school level. Out of 50 respondents $(16 \%)$ had taken a lesson on personal hygiene. From the total of respondents $(46 \%)$ and $(20 \%)$ wash their hands once and twice during working time, respectively. (44\%) of the respondents reported to use detergent. Most of the respondents (84\%) wash their hands after toilet.

From the total of respondents, $(54 \%)$ cleaned the working surfaces between each process and after work. About (70\%) of the respondents wash their working knives after the completion of the work and $(30 \%)$ wash several times during working time.

As on observational assessment, $80 \%$ of the closets of butchers were dirty. Most of the workers (84\%) in the abattoir did not wear aprons and did not wear a hair covering. Also, $66 \%$ of them did not wear any jeweler materials. Overall, the hygienic status of the abattoir was poor.

\section{Findings of questionnaire survey in butcher shops:}

A total of 50 respondents were surveyed from butcher shops. About (28\%) of the butchers were in an educational level of elementary, $(50 \%)$ had completed high school level and $22 \%$ had $\geq 12$ years of education. Also, $14 \%$ of the respondents had taken a lessons on personal hygiene. 
About $54 \%$ and $24 \%$ of the respondents washed their hands twice and once during working time, respectively. Also, $(56 \%)$ of the respondents reported to use a detergent. As observed during the current study, about (86\%) of the respondents wash their hands after using toilet.

Although, about (8\%) of the respondents reported the cashier is handling money, the majority (92\%) of the respondents reported to handle money by themselves. Some of the butchers (44\%) cleaned the working surfaces and most of them $(86 \%)$ reported washing knives after work.

As on observational assessment, $(80 \%)$ of the closets of butchers were dirty, and most of butchers (86\%) didn't wear a hair covering. Wearing of jeweler materials were observed in (24\%) of the butchers. About the hygienic status of the butcher shops, $(70 \%),(26 \%)$ and $(4 \%)$ had poor, moderate and good status, respectively.

\section{Discussion:}

Production of safe food has important economic implications in an increasingly competitive global market (Addis et al., 2011). Listeria species are ubiquitous in nature and have been isolated from wide environmental sources (Liu, 2008). The organism possesses ability to survive in harsh conditions and therefore, can persist in the environment. Because of such persistence Listeria species can easily enter in the food chain. Of the known Listeria species, L. monocytogenes is pathogenic to humans and animals (Pal, 2007; Raorane et al., 2014).

This specific interest is related to the presence of $L$. monocytogenes, one of the most important food-borne pathogens, in the genus. It is often found in various uncooked foods, such as meat, cheese, and vegetables. It is widely diffused in the environment and this fact can cause the contamination of food during production and distribution. However, $L$. monocytogenes has been the main representative of the genus to be studied (Cocolin et al., 2002).

Prevalence of L. monocytogenes in raw camel meat:

The specific prevalence of $L$. monocytogenes based on sample source was found to be statistically significant. In this study, the prevalence of $L$. monocytogenes in camel meat was $6.6 \%$ in abattoir. This is in close agreement with (Pociecha et al., 1991) who noted a prevalence of $3.2 \%$ from carcass in Island and $5 \%$ from carcass in Brazil slaughter house (Ankpolat et al., 2004).

In the current study, the overall prevalence of L. monocytogenes was 4.1. The prevalence was still higher in other country like Australia with $16 \%$ in one study (Ibrahim and Mac Rae, 1991), and $40 \%$ in another (Mac Gowan et al., 1994).

Listeria monocytogenes has been found in different kinds of raw meat; there has been a relatively high prevalence of $20.8 \%$ (Sramova, et al. (2000) and $12.5 \%$ (Karpiskova, 1998).

The prevalence of $L$. monocytogenes $(6.6 \%)$ was found to be in agreement with findings of Ankpolat et al., (2004) who recorded 5\%. On the contrary, there was no detection of $L$. 
monocytogenes at abattoir from carcasses in Germany (Cohen et al., 2006). A high prevalence of $50 \%$ was also reported (Abay et al., (2012).

The study also revealed that the prevalence of $L$. monocytogenes in camel meat was $6.6 \%$ in abattoir and $2.6 \%$ in butcher shops. This is lower than the prevalence reported by Kwiatek et al., (1992) who observed a prevalence of $9.3 \%$ in sheep meat, this could be attributed to the high microbial loads on raw meat entering the process and thus increase the potential for contamination of the processing environment and if separation is not adequately maintained the finished product (Gilbert et al., 2009).

In New Zealand, a prevalence of $30 \%$ L. monocytogenes was recorded by Gilbert et al., (2009) which was very high than the current study reported $(6.6 \%)$ prevalence in abattoir. The reason for this difference could be attributed to the different hygienic conditions of slaughter houses, storage and processing in different countries. In Ethiopia only few researches were done on this, by Molla et al., (2004) who observed a prevalence of $5.1 \%$ in raw and ready to eat food products, whereas another study revealed a prevalence of $5.4 \%$ from raw meat, milk and milk products (Firehiwot, 2007).

Another study reported a prevalence of $4.0 \%$ of $L$. monocytogenes from carcasses in slaughter houses (Al Ali, et al., (2012). Also, several studies reported a prevalence of $4 \%$ in ready to eat foods (Ndahi et al., (2013), 2.4\% from meat and meat products in Morocco (Ennaja et al., (2008) and 4.7\% from meat products in turkey (Yucel et al., (2005).

In the present study, the equipments were potential source of contamination with a prevalence of $7.6 \%$ which was lower than that reported by Lowry and Tiong (1988) and Dunja (2011) who reported $13 \%$ and $11.4 \%$ prevalence of $L$. monocytogenes in food contact surfaces, respectively.

This study reported a prevalence of $7.6 \%$ of $L$. monocytogenes. Which was lower than $25.64 \%$ which was reported by Jankuloski et al., (2007).

The variation of prevalence in the two study sites may be because of environmental contaminations and poor sanitary conditions while handling of the meat before reach to the consumer.

Therefore, based on the above results the following recommendations are forwarded:

Understanding the sources of the pathogen and factors that contribute to the risk of contamination, growth and spread of the pathogen are important building blocks to an effective control program, creating public awareness by disseminating the information is necessary and an extensive survey of the prevalence of L. monocytogenes in whole of Sudan must be undertaken. 
Tables:

Table (1): Distribution of the type and number of samples collected.

\begin{tabular}{|c|c|c|}
\hline \multicolumn{2}{|c|}{ Type of sample } & $\begin{array}{c}\text { Number of } \\
\text { samples }\end{array}$ \\
\hline \multirow{4}{*}{$\begin{array}{c}\text { Camel meat swab } \\
\text { samples }\end{array}$} & Neck & 190 \\
\cline { 2 - 3 } & Shoulder & 190 \\
\cline { 2 - 3 } & Thigh & 190 \\
\cline { 2 - 3 } & Liver & 190 \\
\hline \multirow{3}{*}{$\begin{array}{c}\text { Equipments } \\
\text { samples }\end{array}$} & knives & 50 \\
\cline { 2 - 3 } & Cutting tables & 40 \\
\cline { 2 - 3 } & Hooks & 15 \\
\hline \multicolumn{2}{|c|}{ Total } & 865 \\
\hline
\end{tabular}

Table (2): Overall prevalence of Listeria monocytogenes from different source of samples:

\begin{tabular}{|c|c|c|c|}
\hline Sample Type & No. examined & No. +ve $(\%)$ & $95 \%$ CI \\
\hline Abattoir & 380 & $25(6.6)$ & $3.4-9.8$ \\
\hline Butcher & 380 & $10(2.6)^{*}$ & $0.4-4.8$ \\
\hline Cutting table & 40 & $3(7.5)^{*}$ & $3.4-11.6$ \\
\hline Hook & 15 & $0(0.0)$ & - \\
\hline Knife & 50 & $5(10)$ & $5.7-14.3$ \\
\hline Total & 865 & $48(5.5)$ & - \\
\hline
\end{tabular}

*Proportions $(\%)$ with similar letters are not statistically significant (with p-value $=0.05$ ).

$\mathrm{CI}=$ confidence interval; $\%=$ percent of prevalence.

Table (3): Prevalence of Listeria monocytogenes and association with different sources of samples:

\begin{tabular}{|c|c|c|c|c|c|c|c|}
\hline $\begin{array}{c}\text { Source of } \\
\text { sample }\end{array}$ & $\begin{array}{c}\text { No. of } \\
\text { examined }\end{array}$ & $\begin{array}{c}\text { Total } \\
\text { positive }\end{array}$ & $\begin{array}{c}\text { Prevalence } \\
(\%)\end{array}$ & OR & CI of OR & $\chi^{2}$ & P-value \\
\hline Butchers & 380 & 10 & 2.6 & 1 & - & - & - \\
\hline Abattoir & 380 & 25 & 6.6 & 3.1 & $2.1-7.2$ & 7.1 & 0.01 \\
\hline Total & 760 & 35 & 4.6 & - & - & - & - \\
\hline
\end{tabular}

$\mathrm{OR}=$ odds ratio $\mathrm{CI}=$ confidence interval; $\chi 2=$ Chi square. 
Table (4): Prevalence of listeria monocytogenes in meat contact surface materials:

\begin{tabular}{|c|c|c|c|c|c|}
\hline $\begin{array}{c}\text { Source of } \\
\text { sample }\end{array}$ & $\begin{array}{c}\text { No. } \\
\text { examined }\end{array}$ & Total positive & $\begin{array}{c}\text { Prevalence } \\
(\%)\end{array}$ & $\chi^{2}$ & P-value \\
\hline Hook & 15 & 0 & 0.0 & - & - \\
\hline Cutting table & 40 & 3 & 7.5 & 3.6 & 0.1 \\
\hline Knife & 50 & 5 & 10 & - & - \\
\hline Total & 105 & 8 & 7.6 & - & - \\
\hline
\end{tabular}

Table (5): Summary of observational assessment and knowledge of workers on hygienic practices in the abattoir:

\begin{tabular}{|c|c|c|c|}
\hline Abattoir activity & Performance & $\begin{array}{c}\text { No. of } \\
\text { respondents }\end{array}$ & $\begin{array}{c}\text { Percent } \\
(\%)\end{array}$ \\
\hline \multirow{3}{*}{ Years of education } & $1-8$ & 35 & 70 \\
& $9-11$ & 10 & 20 \\
& $\geq 12$ & 5 & 10 \\
\hline Lessons on personal hygiene & Yes & 8 & 16 \\
& No & 42 & 84 \\
\hline \multirow{3}{*}{ Frequency of washing hands } & Once & 23 & 46 \\
& Twice & 10 & 20 \\
& Other & 17 & 34 \\
\hline \multirow{2}{*}{ Washing of hands } & With water only & 28 & 56 \\
& With detergent & 22 & 44 \\
\hline Washing of hands after toilet & Yes & 42 & 84 \\
& No & 8 & 16 \\
\hline Clean and disinfected working & Before work & 23 & 46 \\
& Between each & 27 & 54 \\
& process & & \\
\hline Warfaces & After work & 35 & 70 \\
& Between process & 15 & 30 \\
\hline View of closets & Neat & 10 & 20 \\
& Dirty & 40 & 80 \\
\hline Wearing of aprons & Yes & 8 & 16 \\
& No & 42 & 84 \\
\hline Hair & Covered & 8 & 16 \\
& Not covered & 42 & 84 \\
\hline \multirow{2}{*}{ Wearing of jeweler materials } & Worn & 17 & 34 \\
& Not worn & 33 & 66 \\
\hline
\end{tabular}


Table (6): Summary of observational assessment and knowledge of workers on hygienic practice in butcher shops:

\begin{tabular}{|c|c|c|c|}
\hline Abattoir activity & Performance & $\begin{array}{l}\text { No. of } \\
\text { responden } \\
\text { ts }\end{array}$ & $\begin{array}{l}\text { Percent } \\
(\%)\end{array}$ \\
\hline \multirow{3}{*}{ Years of education } & $1-8$ & 14 & 28 \\
\hline & $9-11$ & 25 & 50 \\
\hline & $\geq 12$ & 11 & 22 \\
\hline \multirow[t]{2}{*}{ Lessons on personal hygiene } & Yes & 7 & 14 \\
\hline & No & 43 & 86 \\
\hline \multirow[t]{3}{*}{ Time interval of washing hands } & Once & 12 & 24 \\
\hline & Twice & 27 & 54 \\
\hline & Other & 11 & 22 \\
\hline \multirow[t]{2}{*}{ Washing of hands } & With water only & 22 & 44 \\
\hline & With detergent & 28 & 56 \\
\hline \multirow[t]{2}{*}{ Washing of hands after toilet } & Yes & 43 & 86 \\
\hline & No & 7 & 14 \\
\hline \multirow{2}{*}{$\begin{array}{c}\text { Clean and disinfect working } \\
\text { surfaces }\end{array}$} & Before work & 28 & 56 \\
\hline & $\begin{array}{l}\text { Between each } \\
\text { process }\end{array}$ & 22 & 44 \\
\hline \multirow[t]{2}{*}{ Washing of knives } & After work & 43 & 86 \\
\hline & Between process & 7 & 14 \\
\hline Handling money & $\begin{array}{l}\text { Cashier } \\
\text { Butcher }\end{array}$ & $\begin{array}{c}4 \\
46\end{array}$ & $\begin{array}{c}8 \\
92\end{array}$ \\
\hline \multirow[t]{2}{*}{ View of closets } & Neat & 10 & 20 \\
\hline & Dirty & 40 & 80 \\
\hline \multirow[t]{2}{*}{ Hair covering } & Covered & 8 & 14 \\
\hline & Not covered & 42 & 86 \\
\hline \multirow[t]{2}{*}{ Wearing of jeweler materials } & Worn & 12 & 24 \\
\hline & Not worn & 38 & 76 \\
\hline \multirow{3}{*}{$\begin{array}{c}\text { Hygienic status of the butcher } \\
\text { shop }\end{array}$} & Good & 2 & 4 \\
\hline & Moderate & 13 & 26 \\
\hline & Poor & 35 & 70 \\
\hline
\end{tabular}




\section{Figures:}

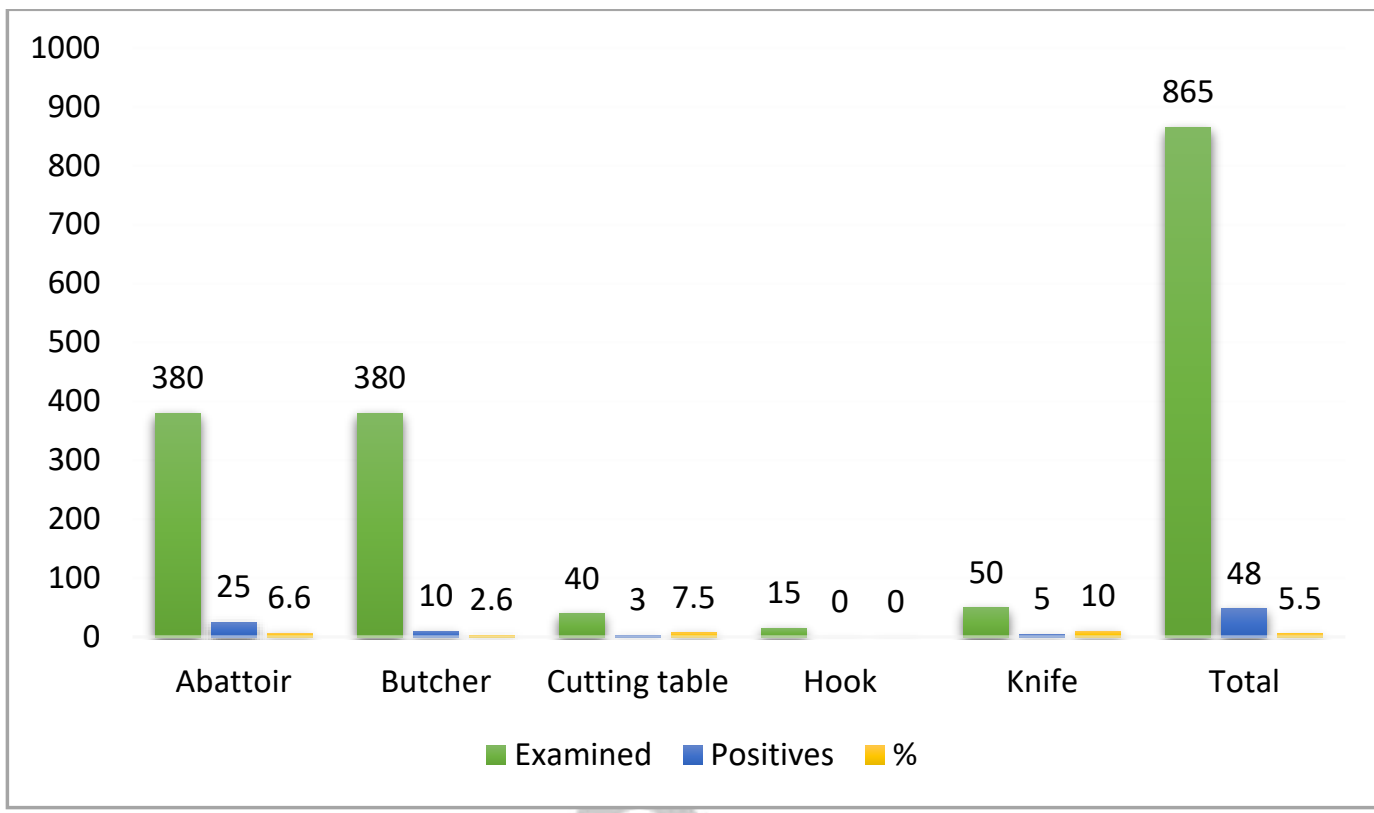

Figure (1): Overall prevalence of L. Monocytogenes.

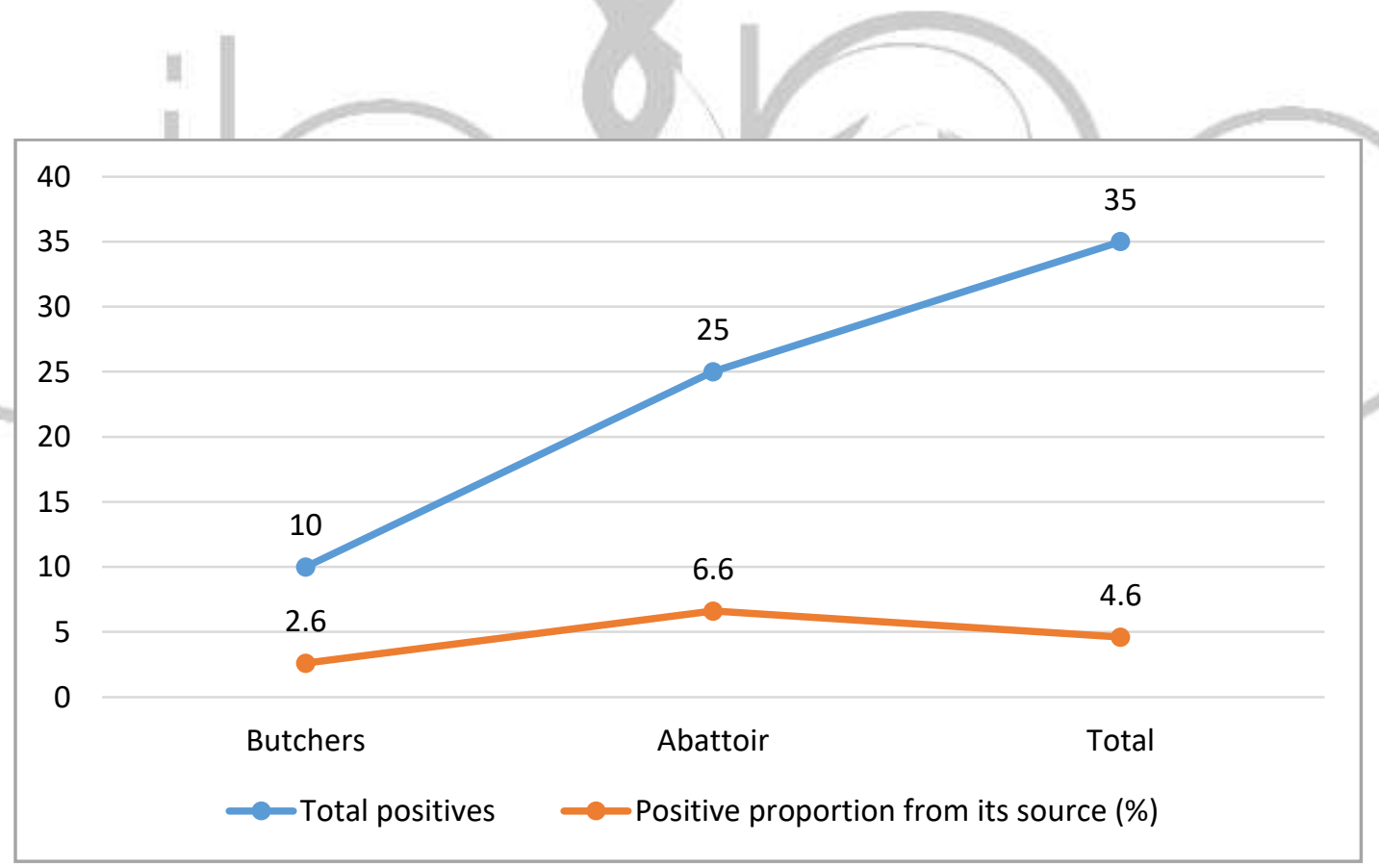

Figure (2): Proportion of positive prevalence in butcher shops and abattoir. 


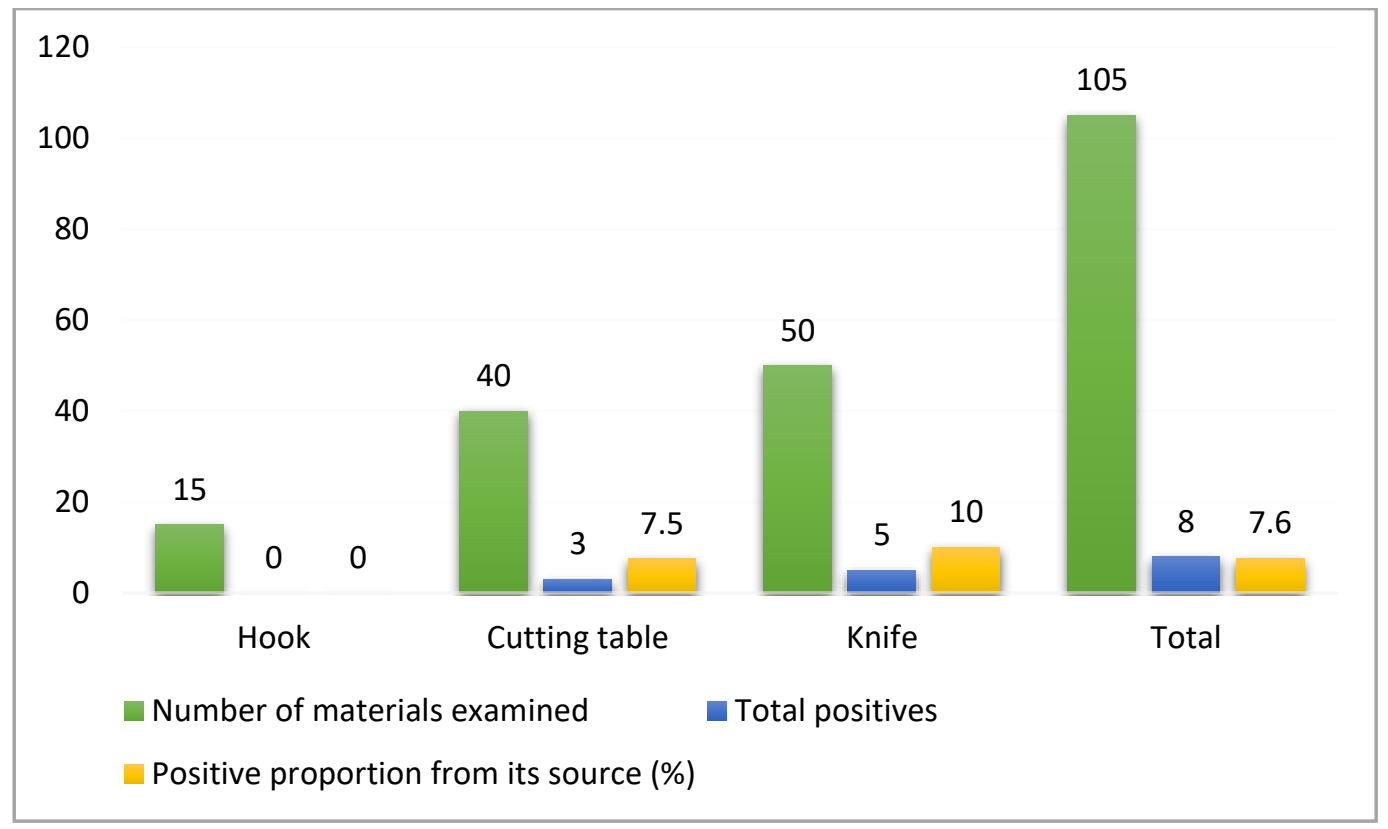

Figure (3): The positive proportion of the surface materials to L. monocytogenes.

\section{REFERENCES}

Ajiboye, E.A., Alhassan, A.S., Majekodunmi, K.R., Oladosu, M., Tolu, O., (2011). Physicochemical properties and microorganisms isolated from dried meat obtained in OjaOba market in llorin, Nigeria. Adv. Appl. Sci. Res. 2 (4):391-400.

Ali AA (2007). Prevalence of bacterial contamination of public health concern on bovine carcasses at Khartoum state- Sudan. M.Sc. Thesis Sudan University of Science and Technology, Sudan.

Al Ali, H. G. K., Alrodham, M. A. and Almohana, A. M. (2012): Isolation of Listeria monocytogenes from gallbladder of sheep and cattle in slaughter house Najaf. Kufa Journal of Veterinary Medical Sciences. Vol. (3) No. (1).

Ankpolat, N. O., Elci, S., Atmaca, S. and Gul, K. (2004): Listeria monocytogenes in products of animal origin in Turkey. Journal of Veterinary Research Communication. 28(7):561-7.

Abay, S., Aydin,F. and Sümerkan, A. B. (2012): Molecular typing of Listeria spp. isolated from different sources. Ankara Üniversity of Veterinary Fak Derg, Department of Microbiology, Acbadem Medical Center, Kayseri, Turkey. 59, 183-190.

Arnold international students, 1993. Food poisonings surface finishing of some materials commonly and food hygiene 6th Rev. Edn., Replika press Pvt. used in food industries. J. Food Eng. Ltd., Delhi, India. 165: 48-53. 
Burfoot D, K Brown, Y Xu, SV Reavell, K. Hall. (2000). Localized air delivery systems in the food industry. Trends in Food Sci and Techn. Volume 11, Issue 11. Pages 385-430.

Borch, E., Kant-Muermans, M-L. And Blixt, Y., (1996). Bacterial spoilage of meat and cured meat product. Int. J. Food Microbial. 33(1): 103-120.

Butterorth-Heineinann, 2000. The science of food hygiene. 3rd Edn. Reed Educational and professional publishing Itd London, U.K.

CDC, (2011): National Center for Zoonotic, Vector-Borne, and Enteric Diseases, "Listeriosis General Information and Frequently Asked Questions," available at http://www.cdc.gov/nczved/divisions/dfbmd/diseases/listeriosis/.

Cocolin, L., Rantsiou, K., Iacumin, L., Cantoni,C. and Comi, G. (2002):Direct Identification in Food Samples of Listeria spp. and Listeria monocytogenes by Molecular Methods. Journal of Applied and Environmental Microbiology. 68(12):6273-82.

Cohen, N., Ennaji, H., Hassar, M. and Karib, H. (2006): The bacterial quality of red meat and offal in Casablanca (Morocco). Journal of Molecularand Nutritional Food Research.

Doyle MP, (1991). Escherichia coli O157:H7 and its significance in food.Int. J. Food Microbiol. 12(4):289-301.

Dunja, L. (2011): The microbiological effects of poor slaughter and processing hygiene in mutton production as determined by various marker organisms. 96(5):135-144.

EFSA (2007): The community summary report on trends and sources of zoonoses, zoonotic agents and antimicrobial resistance and foodborne outbreaks in the European Union in 2006 The EFSA Journal.

Elmossalami, E. and N. Wassef, 1971. Penetration of some microorganisms in meat. Zbl. Vet. Med. B. 5: 277-283.

Ennaji, H., Timinouni, M., Ennaji, M., Hassar, M. and Cohen, N. (2008): Characterization and antibiotic susceptibility of Listeria monocytogenes isolated from poultry and red meat in Morocco. Journal of Infectious Drug Resistance. 1: 45-50.

FDA (2012): Bad bug book: Foodborne pathogenic microorganisms and natural toxins handbook, 2nd ed. US Food and Drug Administration, Silver Spring.

Firehiwot, A. (2007): Prevalence and antimicrobial profile of Listeria monocytogenes in retail meat and dairy products in Addis Ababa and its surrounding towns, Ethiopia. MSc. Thesis, Addis Ababa University Department of Microbiology, Immunology, and Parasitology, Faculty of Medicine, Addis Ababa, Ethiopia. 4(1):22-9.

Forsythe, S.J. and P.R. Hayes, 1998. Food hygiene, Microbiology and HACCP, 3rd Rev. Edn. A. Chapman and Hall food science book. Aspen Publishers, Inc., Garthersburg, M.D., U.S.A.

Gilbert, S., Lake, R. Hudson, A. and Cressey, P. (2009): Risk Profile: Listeria monocytogenes in processed ready-to-eat meats New Zealand Food Safety Authority contract for scientific 2020 May Edition | www.jbino.com | Innovative Association 
services. Institute of Environmental Science and Research Limited. Pp. 1-82.Goulet, V., Hebert, M., Hedberg, C., Laurent, E. 45(5): 1-66.

Gill, C.O. (2000). HACCP in primary processing red meat. In: Brown, M.H. (Ed.), HACCP in the meat industry, Wood head Publishing, Cambridge. 81-122.

Glimour A, Murry KA, Madden, R.H. (2004). Determination of the principal points of products contamination during beef carcass dressing process in Northern Ireland. J. Food Prot. 67(7):1494-6.

Gracey, J.F. (1986). Gracey, J. F. (1992) Meat hygiene 9thed .Bailliere Tindal - London. Thornton's Meat Hygiene .6th London: Bailliere Tindall.

Grif K., G. Patscheider, M. P. Dierich, F. Allerberger. 2003. Incidence of fecal carriage of Listeria monocytogenes in three healthy volunteers: a one-year prospective stool survey. Eur J Clin Microbiol Infect Dis. 22(1):16-20.

Ibrahim, A. and Mac Rae, I. C. (1991): Incidence of Aeromonas and Listeria spp. in red meat and milk samples in Brisbane, Australia. International Journal of Food Microbiology. 12(23):263-9.

ICMSF, (International commission of Microbiological Specifications for Foods 1998). Microorganisms in Food, Blackie Academic \&Professional. London.

ISO (1996): Microbiology of food and animal feeding stuffs - Horizontal method for the detection and enumeration of Listeria monocytogenes. International Organization for Standardization - Part 1: Detection method. International Standard ISO 11290-1, Geneva, Switzerland.

Jankuloski, D., Sekulovski, P., Prodanov, R., Musliu, Z. H. and Dimzovska, B. S. (2007): Listeria monocytogenescontamination of environment and surfaces of the equipment in the meat processing facilities in republic of Macedonia. Directory of Open Access Journals, Sweden.

Karpiskova, R. (1998): Study of the occurrence of listeria in foodstuffs in 1998 (in Czech). The Bulletin of Centre for the Hygiene of Food Chains in Brno. 7, 8-9.

Kwiatek, K., Wojton, B., Rola, J. and Rozanska, H. (1992): The incidence of Listeria monocytogenes and other Listeria spp. in meat, poultry and raw milk. B. Vet. I. Pulawy. 35, 711.

Lawrie, E.A., 1979. Meat science. 3rd Edn. Pregamon Press, Oxford, UK

Liu, D., Lawrence, M., Austin, F. W. and Ainsworth, A. J. (2005): Comparative assessment of acid, alkali and salt tolerance in Listeria monocytogenes virulent and a virulent strains. FEMS Microbiology Letter. Volume 243, Pages 373-378. 
Lowry, P. D. and Tiong, I. (1988): The incidence of Listeria monocytogenes in meat and in meat products-factors affecting distribution. In: (eds). Proceedings of 34th International Congress of Meat Science and Technology. Brisbane, Australia.

Molla, B., Yilma, R. and Alemayehu, D. (2004): Listeria monocytogenes and other Listeria species in retail meat and milk products in Addis Ababa, Ethiopia. Ethiopian Journal of Health Development. 18(3):208- 212.

Ndahi, M.D., Kwaga, J. K. P., Bello, M., Kabir, J., Umoh, V.J., Yakubu, S. E. and Nok, A. J. (2013): Prevalence and antimicrobial susceptibility of Listeria monocytogenes and methicillinresistant Staphylococcus aureus strains from raw meat and meat products in Zaria,Nigeria. Letters in Applied Microbiology. 58(3):262-9.

Neil Trent, Peter Ormel, Jose Luis Garcia de Silas, Gunter Heins and Morgane James, 2002. State of meat food in developing countries. 62: 381-390.

Nesbakken, T., G. Kapperud, and D. A. Caugant. 1996. Pathways of Listeria monocytogenes contamination in the meat processing industry. Int. J. Food Microbiol. 31 (1-3):161-71.

Pal, M. (2007): Zoonoses. 2nd ed. Satyam Publishers, Jaipur, India. Pp. 145-147.

Raorane, A., Doijad, S., Katkar, S., Pathak, A., Poharkar, K., Dubal, Z. and Barbuddhe, S. (2014): Prevalence of Listeria species in animals and associated environment. Journal of Advances in Animal and Veterinary Sciences, 2: 81-85.

Sramova, H., Benes, C. and Karpiskova, R. (2000): Listeriosis in the Czech Republic and around the world (in Czech). The Bulletin of Centre of Epidemiology and Microbiology Prague. 62(3):197-209.

Thrustfield, M. (2005): Veterinary Epidemiology. 3rd ed. Blackwell Science Ltd. Cambridge, USA.

Yucel, N., Citak, S. and Onder, M. (2005): Prevalence and antibiotic resistance of Listeria species in meat products in Ankara, Turkey. Journal of Food Microbiology. 22(2-3):241-245. 